KAWISTARA

VOLUME 5

No. 2, 17 Agustus 2015

Halaman 99-220

\title{
KONDISI HUTAN BAKAU TEBANGAN MASYARAKAT DAN INDUSTRI PULP DI BATU AMPAR KALIMANTAN BARAT
}

\author{
Tjut Sugandawaty Djohan \\ Fakultas Biologi Universitas Gadjah Mada \\ Email:tjutdjohan@ugm.ac.id \\ P.M. Laksono, Esti Anantasari, dan Angga N. Utama \\ Pusat Studi Asia Pasifik Universitas Gadjah Mada \\ Krisni Suhesthiningsih \\ Fakultas Biologi Universitas Gadjah Mada
}

\begin{abstract}
The purpose of this research was to study tree cutting of mangrove forest by the local people of Batu Ampar and the pulp industry at Kapuas river estuary. At each site the rapid measurement methods were established using quadrate plots of $20 \mathrm{~m} \times 20 \mathrm{~m}$ and $5 \mathrm{~m} \times 5 \mathrm{~m}$, each with 2 replicates. The results revealed that the local people only cut the selective trees of Rhizophora apiculata and Bruguiera gymnorhiza with diameter of $20-25 \mathrm{~cm}^{2}$ at 0.25 ha wide, which created gap canopy as small disturbace to the mangrove forest. This area of gap canopy immediately was colonized and dominated by R. apiculata. The mangrove tree cuttings created the phase gap generations. This forest recovered quickly, thus the small distrurbance maintained the mangrove tree species diversity. The Rhizophora roots were habitat for nusery grown of larval shrimps, crabs, and fishes. The pulp industry cut all of the mangrove species wich created big disturbance and huge gap area. The forest also recovered quickly, but was dominated by Xylocarpus granatum. Thus, the big disturbance by the pulp industry caused the shifted species of the mangrove forest species from Rhizophora and Bruguiera to Xylocarpus. The roots of Xylocarpus tree were not habitat forthelarval shrimps, crabs, and fishes, which decreased the fisherman catch. The forest rehabilitation of industrial cutting was planted regularly with Rhizophora, and created many current canals which proned to the erosion. Thus the pulp industry of mangrove forest cutting threatened nursery habitat and species diversity at the mangrove forest of Batu Ampar.
\end{abstract}

Keywords: Mangrove, Local tree cutting, Industrial cutting, Disturbance, Forest recovery

\footnotetext{
ABSTRAK

Tujuan penelitian hutan bakau Batu Ampar di muara Sungai Kapuas adalah untuk mempelajari hasil tebangan masyarakat dan tebangan oleh industri pulp. Pada setiap lokasi kajian, metode yang digunakan adalah rapid measurement dengan bantuan kuadrat plot $20 \mathrm{~m} \times 20 \mathrm{~m}$ dan $5 \mathrm{~m} \times 5 \mathrm{~m}$ masingmasing dengan ulangan dua kali. Hasil mengungkapkan tebangan hutan bakau masyarakat dalam skala kecil 0,25 ha dan telah menciptakan usikan kecil terhadap hutan bakau. Masyarakat menebang hanya pohon Rhizophora apiculata dan Bruguiera gymnorhiza dengan diameter $20-25 \mathrm{~cm}^{2}$. Hutan bakau Batu Ampar bekas tebangan masyarakat disusun oleh banyak generasi fase gap yang tumbuh alami.
} 
Tebangan skala kecil hutannya pulih cepat dan telah menjaga biodiversitas jenis penyusun hutan bakau.Area tebangan masyarakat didominasi R. apiculata. Akar Rhizophora merupakan habitat larva udang, ikan, dan kepiting. Tebangan industri menebang semua jenis pohon bakau dalam skala luas dan telah menciptakan usikan sangat besar. Pemulihan alami hutannya cepat akan tetapi didominasi oleh pohon Xylocarpus granatum. Usikan besar telah menyebabkan shifted jenis pohon penyusun hutan bakau Rhizopora dan Bruguiera menjadi Xylocarpus. Akarnya bukanlah habitat untuk larva udang, kepiting, dan ikan. Reboisasi hutan tebangan industri, Rhizophora, ditanam teratur telah menciptakan banyak kanal arus dan dapat menyebabkan erosi.Tebangan industri telah mengancam fungsi hutan bakau Batu Ampar sebagai habitat nusery dan diversitas spesies penyusun hutan bakau.

Kata kunci:Hutanbakau,Tebangan masayarakat, Tebangan industri, Usikan, Pemulihan hutan

\section{PENGANTAR}

Hutan bakau Batu Ampar terletak di muara Sungai Kapuas dan luasnya sekitar 65.585 hektar. Hutan tersebut terdiri dari hutan lindung 33.402 ha dan hutan produksi 32.183 ha. Tipe hutan bakau tersebut merupakan kombinasi antara hutan bakau tepi tumbuh yang kearah darat (fringing mangrove) dan hutan sungai (riverine mangrove). Hutan tersebut didominasi oleh pohon Rhizophora apiculata, Bruguiera gymnorhiza, dan di selingi oleh nyireh (Xylocarpus granatum). Hutan bakau Batu Ampar dipanen baik oleh masyarakat lokal dan maupun oleh industri pulp (bubur kertas) (Laksono dkk, 2014).

Ekosistem hutan bakau disusun oleh berbagai jenis pohon penyusun hutan bakau. Penamaan untuk ekosistem secara ekologi dapat berdasarkan nama pohon yang mendominasi ekosistem tersebut (Odum 1971). Oleh sebab itu, pohon bakau (Rhizophora spp) yang paling dominan di hutan rawa riverine mangrove tersebut, maka nenek moyang telah memberi nama ekosistem rawa tersebut sebagai hutan bakau. Sebagai suatu ekosistem, hutan bakau tidak hanya terdiri dari pohon bakau, Rhizophora spp. saja, tetapi hutan bakau juga disusun oleh berbagai jenis antara lain pohon, semak, liana semak, paku, dan palem bakau; contonya, di hutan bakau Segara Anakan Cilacap, Soerjowinoto (1982) melaporkan bahwa ditemukan 27 jenis penyusun hutan bakau yang termasuk dalam growth form pohon, palem, semak, liana, dan paku bakau. Pada saat ini di hutan bakau tersebut hanya ditemukan sekitar 12 jenis terdiri dari pohon, palem, semak, dan liana semak. Kondisi hutan bakau tersebut juga rusak dan didominasi semak dan liana bakau (Djohan 2007; Djohan dkk. 2014).

Di hutan bakau Batu Ampar, sejak tahun lima-puluhan masyarakat lokal telah memanen pohon Rhizophora apiculata, dan Bruguiera gymnorhiza untuk arang.Arang dari Batu Ampar sangat terkenal kualitasnya. Disamping tebangan hutan oleh masyarakat dalam skala kecil, hutan bakau Batu Ampar juga dipanen dalam skala sangat luas untuk industri pulp. Pada tahun 2006 industri pulp mendapat izin pemanfatan hutan seluas 10.100 ha, dan izin berlaku sampai tahun 2021. Penebangan industri adalah pada skala luas untuk semua jenis penyusun hutan bakau. Tebangan hutan bakau baik oleh masyarakat maupun industri menghasilkan usikan (disturbance) pada ekosistem tersebut baik skala kecil maupun besar. Vogt et al. (2014); Barbour et al. (1987) menyatakan bahwa usikan di berbagai hutan mempunyai peran yang besar dalam dinamika hutan.Usikan merupakan kekuatan utama dalam suksesi hutan.

\section{Klasifikasi Hutan Bakau}

Hutan bakau yang tumbuh berkembang di suatu area adalah merupakan respon komunitas penyusun hutan bakau terhadap hasil kondisi topografi, tipe substrat, hidrologi, ombak, juga tinggi pasang surut, lama genangan pasang, dan salinitas. Semula hutan bakau dipilah dalam enam kelas berdasarkan kondisi hidrologi dan kondisi fisik. Kemudian klasifikasi tersebut disederhanakan menjadi empat kelas utama dengan tipe: (1) Hutan bakau tepi (fringe mangrove), juga termasuk pulau yang disapu air pasang (overwash island); (2)Hutan bakau sungai (riverine 
mangrove); (3) Basinmangrove; (4) Hutan bakau kate (Dwarf atau scrubmangrove) (Mitsch dan Gosselink 2000).

Fringe mangrove ditemukan sepanjang pantai terlindung juga sepanjang kanal sungai dan laguna. Pada lokasi kajian Batu Ampar, hutan bakaunya ditemukan sepanjang kanal dan sungai. Oleh sebab itu, hutan bakau Batu Ampar dapat diklasifikasikan dalam dua tipe: (1) hutan fringe mangrove (hutan bakau tepi) dan (2) riverine mangrove (hutan bakau sungai). Tipe fringemangrove (bakau tepi) tersebut umum ditemukan di sepanjang pantai yang mempunya area lebih tunggi dari rata-rata pasang. Akan tetapi, hutan tersebut terpapar pasang surut harian. Fringe mangrove cenderung mengakumulasi serpihan bahan organik, potongan kayu,dan daun. Sedangkan riverine mangrove ditumbuhi pohon tinggi dan ditemukan di sepanjang tepi sungai.

Ekosistem hutan bakau merupakan ekosistem berbasis detritus dan mempunyai peran yang besar dalam jejaring makanan. Peran tersebut mendukung tidak hanya jenis-jenis organisme bernilai ekologi juga organisme bernilai ekonomi seperti: udang, ikan dan kepiting, baik perikanan perairan hutan bakau maupun perairan pantai dan perairan laut lepas (Odum 1971). Oleh sebab itu, hutan bakau yang sehat memberikan jasa terhadap komunitas penyusun ekosistem baik di ekosistem hutan bakau, maupun di ekosistem tetangga dalam bentang laut (sea-scape) perairan pantai dan lepas pantai (Ronback 1999; Ronback dan Primavera 2000).Indonesia merupakan negara kepulauan, di muara sungai, laguna, dan pantai terlindung merupakan habitat hutan bakau. Untuk itu, kehadiran ekosistem hutan bakau yang sehat sangat penting dalam mendukung ekonomi perikanan pantai dan lepas pantai.

Hutan bakau Batu Ampar termasuk dalam Kecamatan Kubu Raya, dan terletak di muara Sungai Kapuas (Gambar 1). Setelah industri pulp beroperasi tahun 2006, masyarakat mengeluhkan bahwa tangkapan udang, kepiting, dan ikan semakin ber- kurang (Laksono et al. 2014). Masyarakat lokal menebang secara selektif dan dalam skala kecil pohon penyusun hutan bakau R. apiculata dan B. Gymnorhiza untuk arang kayu. Sebaliknya tebangan industri pulp di lakukan dalam skala luas dan merupakan tebang habis semua jenis penyusun hutan bakau.

Secara spesifik dipelajari kondisi hutan bakau hasil tebangan masyarakat dan tebangan industri pulp di Batu Ampar Kalimanatan Barat sebagai berikut: (1) Kekayaan jenis penyusun hutan bakau, dan; (2) Densitas setiap jenis; (3) Jenis yang dominan, dan juga tipe akar pohon bakau; (4) Kualitas air meliputi salinitas dan $\mathrm{pH}$. Penelitian ini merupakan bahagian penelitian dalam usaha menuju tata kelola hutan bakau terpadu dan demokratis di Kubu Raya Kalimantan Barat. Kondisi ekosistem hutan bakau bekas tebangan masyarakat dan tebangan industri ini merupakan masukan utama untuk tata kelola hutan bakau di Batu Ampar.

\section{Deskripsi Lokasi Kajian}

Untuk kajian tegakan pohon penyusun hutan bakau, hutan bakau kajian dipilah menjadi lima lokasi (Gambar1; Tabel1) sebagai berikut: (1) Hutan tebangan masyarakat, yaitu di lokasi Cabang Ruan (CR); (2) Hutan di depan Cabang Ruan (DCR); (3) Lokasi kajian di dataran lumpur bekas, mud-flat, pemukiman logger kayu daratan (HPH) di kawasan Batu Air, luasnya sekitar 50m x 100m, dan (4) Bekas base-camp industri pulp di Batu Ampar Kecil (BBI), dan luasnya sekitar 50m x 75m, dan; (5) Hutan tebangan industri pulp, yaitu di lokasi Tanjung 16 (TI). Kajian hutan tebangan tersebut dilakukan pada zona upper-lower. Sedangkan tebangan industri menebang semua jenis pohon bakau pada semua zona.

Kajian ini dilakukan dengan metode rapid measurement, dan data di koleksi dari zona upper lower, kecuali di Batu Ampar Kecil data dicuplik dari hutan bakau zona lower. 


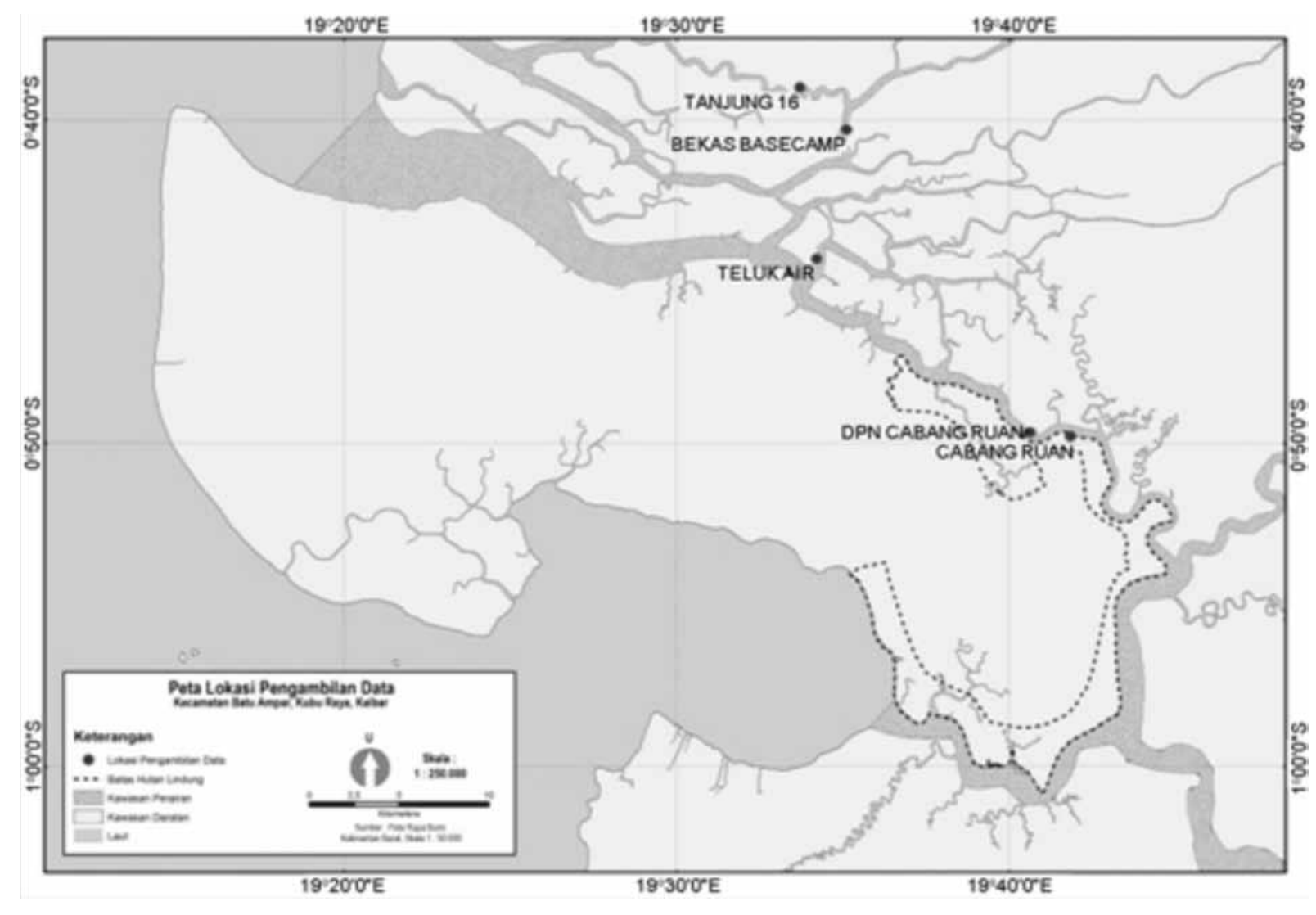

Gambar 1

Lokasi kajian tegakan hutan bakau tebangan rakyat dari selatan ke utara di Cabang Ruan dan Depan Cabang Ruan. Sedangkan di Teluk Air merupakan mudflat bekas base-camp penebang kayu darat; Batu Ampar kecil base camp bekas industri; dan hutan tebangan industri Tanjung 16.

Tabel 1

Posisi GPS lokasi kajian di hutan bakau Batu Ampar Kubu Raya Kalimantan Barat

\begin{tabular}{llll}
\hline No. & Lokasi Kajian & Koordinat GPS & \\
\hline 1 & Cabang Ruan (CR) & $\mathrm{S} 0^{\circ} 49^{\prime} 47,9^{\prime \prime}$ & $\mathrm{E} 109^{\circ} 41^{\prime} 50,7^{\prime \prime}$ \\
2 & Depan Cabang Ruan (DCR) & $\mathrm{S} 0^{\circ} 49^{\prime} 40,2^{\prime \prime}$ & $\mathrm{E} 109^{\circ} 40^{\prime} 37,9^{\prime \prime}$ \\
3 & Teluk Air (TA) & $\mathrm{S} 0^{\circ} 44^{\prime} 18,0^{\prime \prime}$ & $\mathrm{E} 109^{\circ} 34^{\prime} 12,2^{\prime \prime}$ \\
4 & Bekas Basecamp tebangan industri (BCI) & $\mathrm{S} 0^{\circ} 40^{\prime} 18,8$ & $\mathrm{E} 109^{\circ} 35^{\prime} 06,7^{\prime \prime}$ \\
5 & Tanjung 16 (TI) & $\mathrm{S} 0^{\circ} 39^{\prime} 00,4^{\prime \prime}$ & $\mathrm{E} 109^{\circ} 33^{\prime} 42,5^{\prime \prime}$ \\
\hline
\end{tabular}

Pada setiap lokasi kajian, data pohon dicuplik dengan menggunakan kuadrat plot $20 \mathrm{~m} \times 20 \mathrm{~m}$ dengan ulangan dua kali. Pada setiap kuadrat plot tersebut, data sapling dan seedling dicuplik dengan menggunakan sub kuadrat plot $5 \mathrm{~m} \times 5 \mathrm{~m}$ dengan ulangan 2 kali. Parameter yang diukur meliputi cacah jenis penyusun hutan bakau, cacah individu setiap jenis meliputi: tinggi total pohon,dan keliling batang. Juga dicuplik data kualitas air meliputi $\mathrm{pH}$ dan salinitas pada setiap lokasi kajian.

Data pada setiap lokasi kajian ditabulasi, dihitung densitasnya dalam $800 \mathrm{~m}^{2}$, densitas relatif, diameter batang, dan tinggi pohon. Kemudian dipelajari kecendrungan kehadiran jenis dan distribusinya meliputi kemelimpahan pohon, sapling, dan seedlingnya diantara lokasi kajian. 


\section{PEMBAHASAN}

\section{Tipe Hutan Bakau dan Kekayaan Jenis}

Hasil menunjukkan bahwa tipe hutan bakau di lokasi kajian Batu Ampar adalah kombinasi fringe bakau (hutan tepi) dan riverin bakau(hutan sungai). Sepanjang fringe bakau ditemukan hutan bakau campur yang disusun oleh pohon Rhizophora apiculata (buah panjang), Bruguiera gymnorhiza (buah pendek, atau tumuk), Xylocarpus granatum (nyirih), Avicennia alba, dan pohon palem Nypa fruticans. Kemudian kearah Teluk Air juga ditemukan Avicennia alba. Sedangkan di rawa burit hutan bakau yang ditemukan adalah pohon B. gymnorhizadan Acrosticum aureum (paku bakau).Pohon dominannya di tepi sungai adalah R. apiculata, B. Gymnorhiza, dan X. Granatum.

Kekayaan jenis penyusun hutan bakau di Batu Ampar hanya disusun oleh enam cacah jenis, terdiri dari empat jenis pohon, satu jenis palem bakau, dan satu jenis paku bakau. Menarik untuk dicatat bahwa di lantai hutan di lima lokasi kajian sama sekali tidak ditemukan adanya tumbuhan lantai kecuali di rawa burit ditemukan paku A. aureum. Berdasarkan kekayaan jenis, hutanbakau Batu Ampar ini tidak begitu kaya bila dibandingkan dengan hutan bakau Segara Anakan Cilacap pada tahun delapan puluhan, di hutan tersebut ditemukan 23 jenis jenis pohon penyusun hutan bakau dan tiga jenis tumbuhan lantai Acanthus ilicifolius, Derris heterophylladan A. aureum (Soerjowinoto 1982).

\section{Tebangan Pohon Bakau oleh Masyarakat}

Penebangan hutan bakau oleh masyarakat untuk arang dilakukan secara tradisional. Hasil kajian menunjukkan bahwa luas area hutan yang ditebang baik di Cabang Ruan maupun di Depan Cabang Ruan sekitar 0,25 ha. Luas area tebangan pohon bakau tersebut adalah dalam skala kecil dan menciptakan usikan kecil (small disturbance).
Letak hutan tebangan masyarakat adalah di tepi sungai di zona upper-lower dengan jarak 10-15 meter dari tepi sungai kearah zona upper (Gambar 2a). Masyarakat tidak menebang pohon untuk arang tersebut dari zona upper-upper karena letaknya jauh dari tepi sungai dan sulit untuk mengangkutnya ke perahu tradisional (Gambar 2a; 2c).

Masyarakat hanya menebang pohon $R$. apiculata dan B. gymnorhiza dengan diameter tertentu, yaitu sekitar $25 \mathrm{~cm}$. Artinya masyarakat tidak menebang semua pohon penyusun hutan bakau. Sedangkan pohon dengan diameter lebih dari $25 \mathrm{~cm}$ tidak ditebang karena sulit untuk diangkut ke perahu. Oleh sebab itu, dalam area bekas tebangan masyarakat masih ditemukan pohon R. apiculata, B. gymnorhiza yang diameternya lebih besar dari $25 \mathrm{~cm}$. Kedua jenis pohon bakau tersebut merupakan sumber benih propagul pohon bakau untuk tumbuh secara alami. Sebaliknya pohon Xylocarpus granatum tidak ditebang. Oleh sebab itu, di tepi sungai banyak sekali ditemukan pohon $X$. granatum dengan diameter batang sekitar $50 \mathrm{~cm}$ (Gambar 4d).

\section{Kondisi Hutan Tebangan Masyarakat}

Hasil menunjukkan bahwa hutan tebangan masyarakat untuk arang menciptakan gap kanopi. Gap kanopi hutan merupakan usikan kecil. Oleh sebab itu, recovery (pemulihan) pertumbuhan hutannya cepat. Di bekas tebangan hutan Cabang Ruan, hutannya disusun oleh

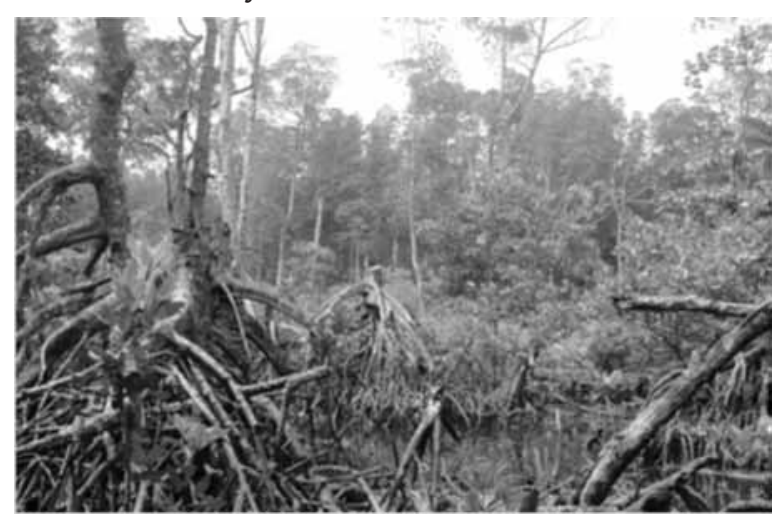

a. Seedling dan sapling R. apiculata 


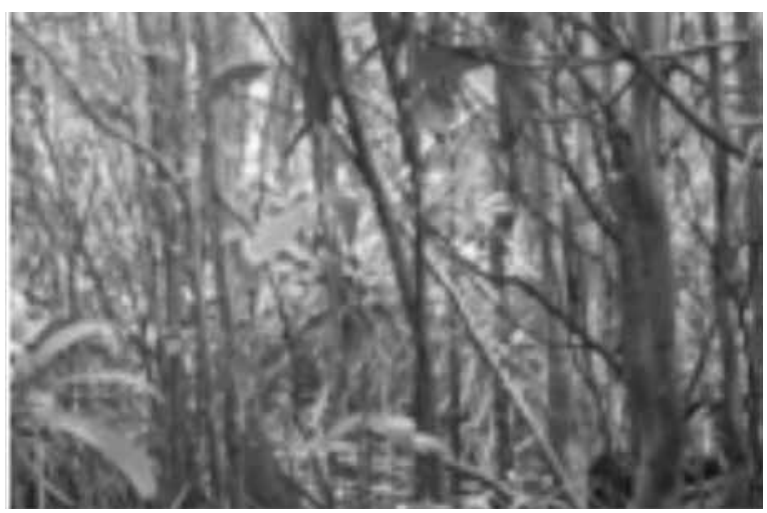

b. Sapling pohon X. granatum

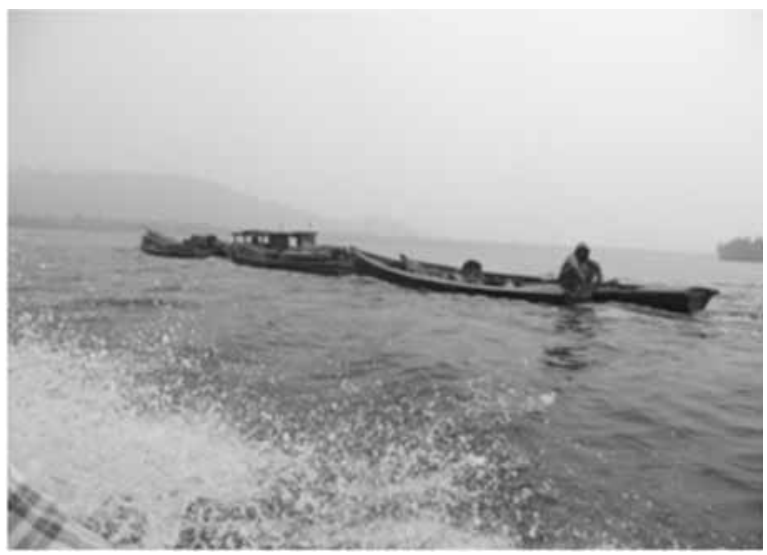

c. Perahu tradisional pengangkut kayu tebangan masyarakat

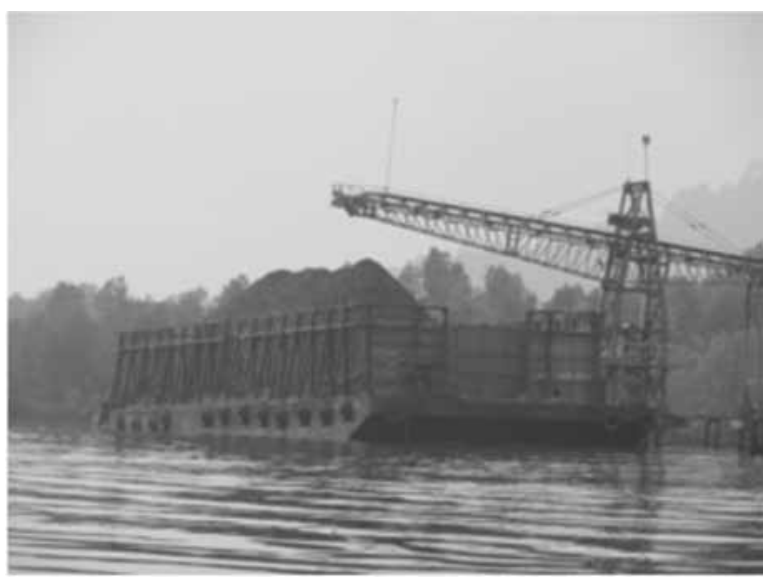

d.Tongkang pengangkut pulp

Gambar 2

a. Seedling dan sapling R. apiculata di bekas tebangan hutan bakau di lokasi kajian Cabang Ruan. Tebangan selektif dalam skala kecil sebagai usikan kecil menciptakan gap kanopi dan secara alami segera dikoloni seedling dan sapling pohon $R$. apiculata. Di dalam lokasi tebangan dan sekelilingnya masih ditemukan pohon $R$. apiculata sebagai sumber propagul; b. Sapling pohon X.granatum di lokasi kajian tebangan industri pulp Tanjung 16. Tebang habis dilakukan dalam skala luas menciptakan usikan besar dan menghasilkan gap area yang luas dan segera dikoloni oleh saplingX. granatum; c. Perahu tradisional pengangkut kayu tebangan masyarakat; $d$. Tongkang pengangkut pulp hasil tebangan industri (Foto T. S. Djohan).

Growthform pohon sapling dan seedling. Pohonnya merupakan pohon sisa yang tidak ditebang. Sedangkan sapling dan seedling adalah tumbuh alami. Hutan tersebut disusun oleh dua jenis pohon $R$. apiculata, dan $X$. granatum, berturut-turut 8 dan 1 individu per $800 \mathrm{~m}^{2}$ dan mempunyai diameter batang berturut-turut 28,04 $\pm 7,12 \mathrm{~cm}$ dan $11,14 \mathrm{~cm}$. Sedangkan sapling dan seedlingnya hanya disusun oleh $R$. apiculata saja. Di lokasi tebangan tersebut tidak ditemukan sapling dan seedlingX.granatum (Gambar 3). Gap kanopi bekas tebangan dikoloni dan didominasi oleh sapling dan seedling $R$. apiculata.

Growth formdominannya adalah seedling R.apiculata dan kehadirannya adalah 3088 individu per $800 \mathrm{~m}^{2}$ dengan tinggi seedlingnya $0,98 \pm 0,16 \mathrm{~m}$. Densitas relatifnya adalah $99 \%$ dari total growth form. Sedangkan saplingnya juga $R$. apiculata adalah 16 individu per $800 \mathrm{~m}^{2}$ dan densitas relatifnya 1\%.Sapling tersebut mempunyai tinggi 1,$24 ; \pm 0,30 \mathrm{~m}$, dan seedlingnya 0,$98 ; \pm 0,16 \mathrm{~m}$. Berdasarkan tinggi seedling dan sapling, dan juga cacah individu seedling pohon yang melimpah, maka diduga lokasi kajian Cabang Ruan ditebang sekitar satu tahun yang lalu.

Sebaliknya di lokasi Depan Cabang Ruan, tidak ditemukan seedling pohon, akan tetapi sapling $R$. apiculata yang hadir adalah 672 individu per $800 \mathrm{~m}^{2}$. Sapling tersebut mempunyai tinggi $1,5 \pm 0,50 \mathrm{~m}$, dan diameter batang nya $13,18 \mathrm{~cm}$ dan densitas relatifnya adalah $98 \%$. Di lokasi ini ditemukan pohon B. gymnorhiza, $R$. apiculata dan $X$. granatum berturut-turut 2; 6; dan 6 pohon per $800 \mathrm{~m}^{2}$, 
dan densitas relatifnya $0,2-87 \%$. Pohon tersebut merupakan sumber propagul untuk seedling B. gymnorhiza dan R. apiculata (Gambar 3). Akan tetapi, dilokasi ini tidak ditemukan seedling pohonnya, maka dapat diestimasi bahwa hutan dibekas tebangan tersebut diperkirakan baru berumur sekitar 2 tahun. Baik di bekas tebangan Cabang Ruan dan Depan Cabang Ruan, berdasarkan kemelimpahan baik seedling atau saplingnya di lokasi tebangan tersebut menunjukkan bahwa pohon dominan di masa depan adalah pohon $R$. apiculata yang diselingi Bruguiera dan Xylocarpus. Artinya tebangan masyarakat tetap menjaga biodiversitas pohon penyusun hutan bakau Batu Ampar. Untuk itu, di hutan bakau bekas tebangan masyarakat di Batu Ampar ditemukan banyak generasi fase gap terutama di zona upper lower.
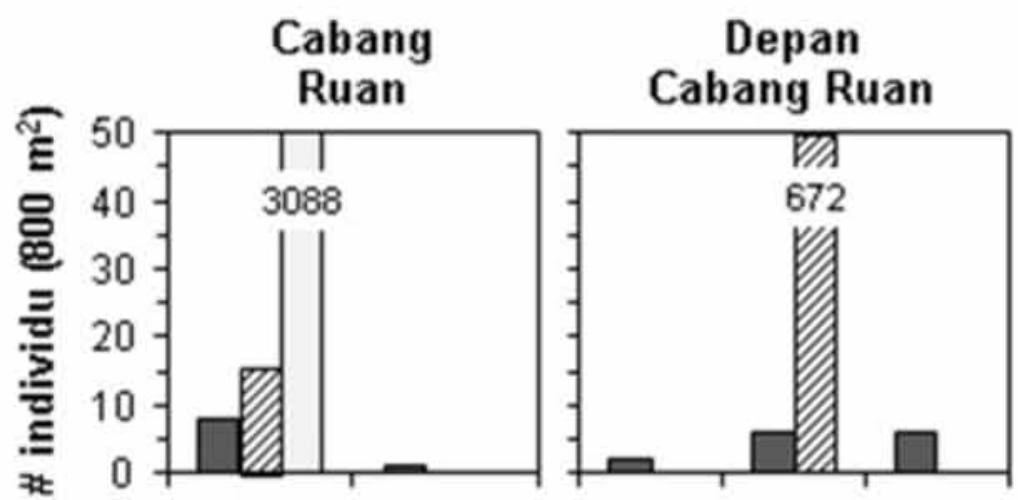

Teluk Bekas Tebangan Air Camp Industri
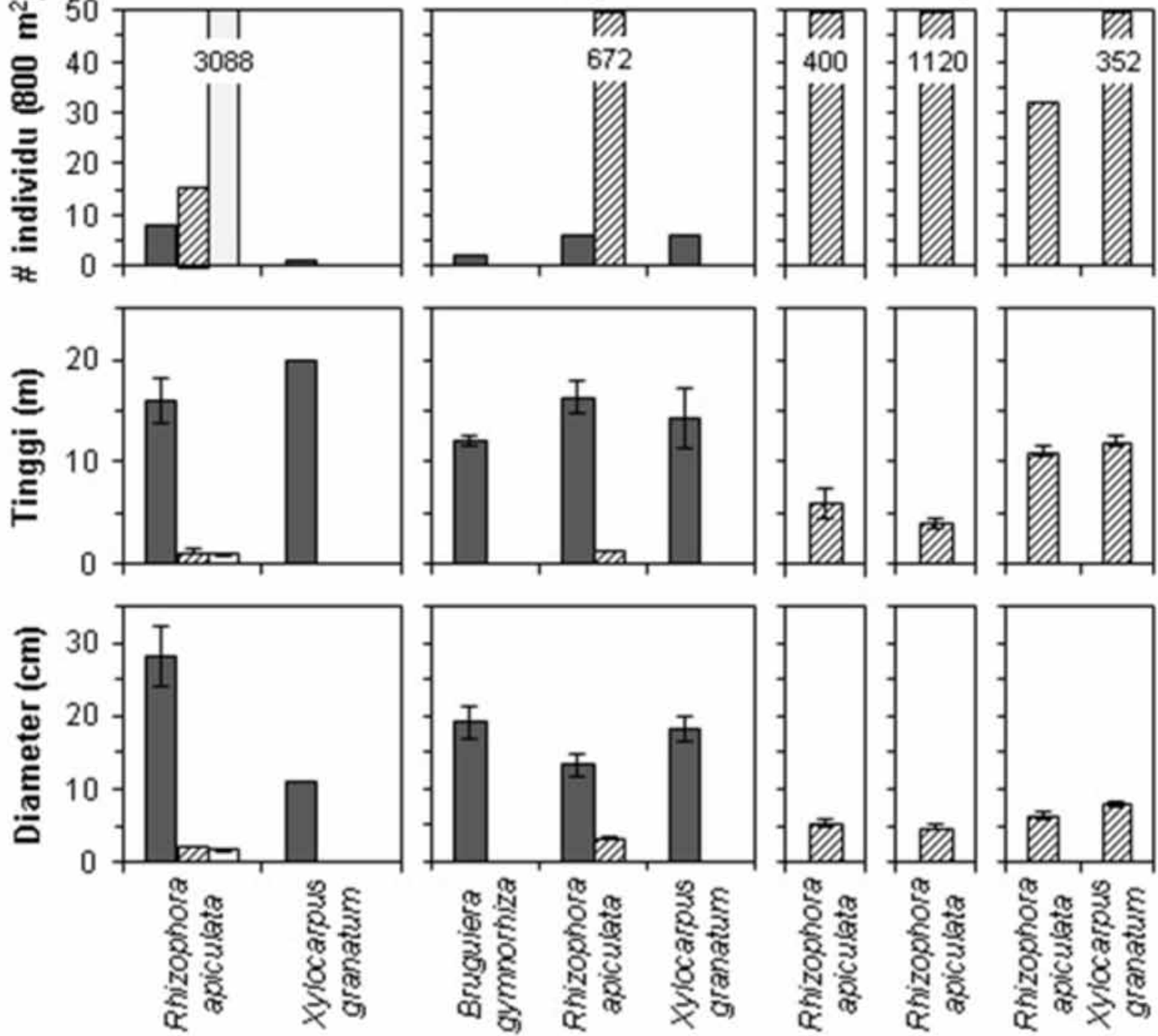

\section{Pohon \\ Sapling \\ Seediing}

Gambar 3

Kemelimpahan pohon, sapling dan seedling di lokasi kajian di hutan bakau tebangan masyarakat Cabang Ruan, Depan Cabang Ruan, bekas base camp logger di Teluk Air dan Batu Ampar Kecil, dan Tebangan industri di lokasi kajian Tanjung 16 
Tebangan Pohon Bakau untuk Industri Pulp

Penebangan pohon bakau untuk industri pulp atau tebangan industri dilakukan dalam skala sangat luas dan menciptakan usikan besar (big disturbance) yang menghasilkan gap area yang luas.Tebangannya adalah tebang habis dan dilakukan mulai dari zona lower-lower sampai zona upper-upper. Penebangan dilakukan untuk semua jenis dan semua ukuran. Jadi tidak ada pohon tersisa misalnya Rhizophora dan Bruguiera sebagai sumber benih propagul seperti hasil tebangan hutan bakau oleh masyarakat. Di hutan bakau Batu Ampar hutan bakau tepi sungainya didominasi oleh pohon $X$. granatum. Oleh sebab itu, untuk di gap area tebangan industri tersebut sumber propagul utamanya adalah X. granatum(Gambar 2b).

Pohon Xylocarpus mempunyai akar papan dan bukanlah habitat pembesaran (nuseryground) untuk larva udang, kepiting dan ikan (Gambar 6c; 6d). Kehadiran dominan pohon $X$. granatum di hutan tebangan industri yang tumbuh alami mengindikasikan bahwa masa depan hutan bakau Batu Ampar dalam keadaan terancam. Apa lagi mengingat bahwa ijin tebangan hutan untuk industri pulp seluas 10.100 ha akan berlangsung sampai tahun 2021 . Campur tangan manusia dalam merehabilitasi hutan bakau rusak pada area usikan besar di hutan bakau Batu Ampar tersebut perlu dilakukan sehingga kelanjutan jasa ekosistem hutan bakaunya tetap berlangsung. Dengan kata lain pertumbuhan hutan bakau di hutan tebangan industri tersebut tidak dapat diserahkan begitu saja kepada alam.

\section{Kondisi Hutan Tebangan Industri Pulp}

Gap area yang terbentuk sangat luas akibat tebangan industri juga tidak tersedianya propagul pohon bakau $R$. apiculata dan B. gymnorhiza sebagai sumber benih. Tidak tersedianya propagul kedua jenis tersebut ternyata telah mengakibatkan area bekas tebangan hampir $92 \%$ dikoloni oleh saplingX. granatum dengan cacah individu 352 batang per $800 \mathrm{~m}^{2}$. Sapling X. granatum tersebut mempunyai tinggi dan diameternya berturut-turut $12 \mathrm{~m}$ dan $8 \mathrm{~cm}$. Sebaliknya sapling $R$. apiculata hanya ditemukan 32 batang per $800 \mathrm{~m}^{2}$, dan densitas relatifnya $8 \%$ dari luas area. Tinggi dan diameternya berturut-turut 11 meter dan 7cm (Gambar 3).

Penebangan dalam skala besar di Tanjung 16 tersebut telah merubah struktur penyusun hutan bakau, dan jenis dominannya sekarang adalah X. Granatum. Oleh sebab itu, di hutan bakau tebangan industri tersebut telah terjadi shifted (pergantian) jenis pohon, yaitu dari $R$. apiculata menjadi X. Granatum (Gambar 2b; Gambar 3). Rejmanek (1984) melaporkan bahwa usikan kecil secara random setiap lima tahun akibat salju longsor di Pegunungan Kronose Czechoslovakia telah menjaga biodiversitas jenis penyusun komunitas hutan spruce di lereng gunung tersebut. Komunitas hutan spruce tersebut terdiri dari rumput, semak dan pohon spruce. Sebaliknya satu usikan besar, salju longsor, yang terjadi di lereng gunung tersebut telah menyebabkan punahnya jenis penyusun komunitas rumput dan semak. Dalam masa 40 tahun, hutan tesebut didominasi hanya oleh pohon spruce saja. Tebangan industri di hutan bakau Batu Ampar dalam skala luas akan meningggalkan satu jenis pohon Xylocarpus dan memusnahkan berbagai jenis pohon penyusun hutan bakau.

Sebaliknya hutan tebangan masyarakat menciptakan usikan kecil secara random tetap menjaga kekayaan jenis penyusun hutan bakau Batu Ampar. Akibat tebangan industri, hutan bakau Batu Ampar akan didominasi oleh X. granatum, dan pohon tersebut akarnya bukan habitat nusery untuk larva udang, kepiting, dan ikan yang bernilai ekonomi.Laksono dkk. (2014) melaporkan bahwa tangkapan nelayan telah berkurang Batu Ampar setelah tebangan industri beroperasi.Hal ini ada kaitannya dengan tebangan skala besar hutan bakau dan dibiarkan tumbuh secara alami, dan telah didominasi oleh jenis pohon bakau Xylocarpus. Akarnya adalah bukan habitat nurcery untuk larva udang, kepiting, dan ikan.

Di hutan bakau Matang Malaysia, Amir (2012) melaporkan bahwa hadirnya gap kanopi akibat sambaran kilat merupakan usikan kecil yang penting dalam dinamika hutan bakau tersebut. Ia menyatakan bahwa 
gap kanopi berisi tegakan pohon yang mati dan seedling pohon bakau baru. Oleh sebab itu, gap kanopi merupakan mesin penggerak regenerasi alami dalam menjaga dominasi Rhizophora di hutan bakau tersebut. Artinya gap kanopi akibat usikan kecil tersebut telah menjaga kondisi hutan bakau Rhizophora di Matang Malaysia. Akan tetapi, seperti telah dibicarakan sebelumnya, tebangan industri di hutan bakau Batu Ampar telah menciptakan usikan besar dan gap area yang luas dan telah merubah struktur penyusun jenis hutan bakaunya. Di hutan tebangan industri, pemulihan hutan alaminya 92\% didominasi oleh pohon Xylocarpus.

Pohon bakau Xylocarpus mempunyai akar papan (Gambar 6c-d). Tipe akar seperti ini adalah bukan habitat untuk larva baik udang, ikan, dan kepiting. Hasil tebangan industri hutan bakau di Tanjung 16 didominasi oleh $X$. granatum karena akarnya merupakan akar papan, maka hutan bakau tersebut telah kehilangan salah satu jasa ekologi hutannya yaitu akarnya sebagai habitat nursery larva baik udang, ikan dan kepiting. Oleh sebab itu, keluhan masyarakat menyatakan bahwa hasil tangkapan udang, ikan, dan kepitingnya berkurang setelah beroperasinya tebangan industri adalah dapat dipahami. Hal ini ada hubungannya dengan perubahan jenis penyusun pohon penyusun hutan bakau di area tebangan industri tersebut. Akibatnya adalah telah tebangan hutan idustri mengurangi hasil tangkapan udang, kepiting, dan ikan nelayan Batu Ampar.

\section{Reboisasi Hutan Tanaman Industri}

Pada area bekas tebangan industri di Batu Ampar Kecil, lokasi tersebut telah direboisasai dengan pohon R. Apiculata tingginya sekitar 6 meter. Akan tetapi, penanaman pohon tersebut adalah dilakukan secara teratur dan telah menciptakan banyak kanal arus yang dapat menyebabkan terjadinya erosi (Gambar 4). Adanya keluhan nelayan bahwa hasil tangkapannya

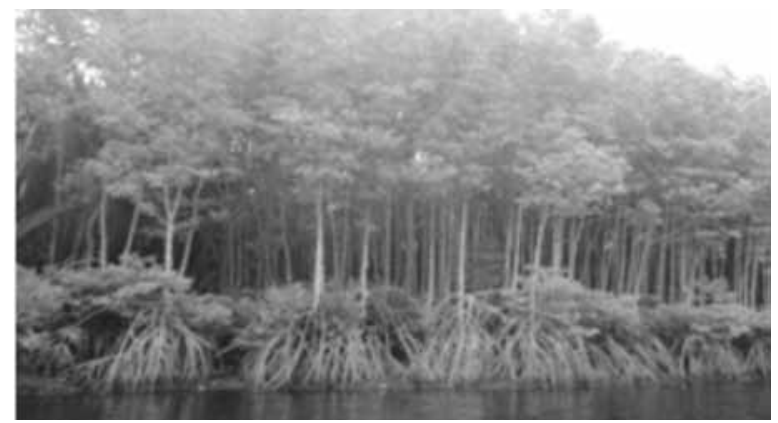

a.

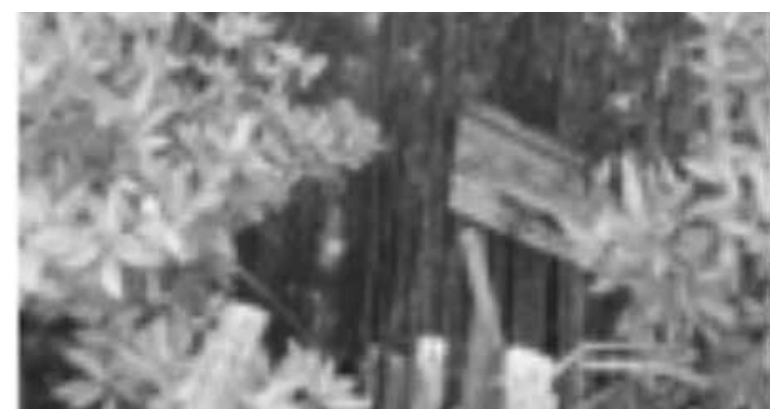

b.

Gambar 4

(a) Hutan R. apiculata merupakan hutan reboisasi bekas tebangan industri di Batu Ampar Kecil. Penanamannya sangat teratur, dan; (b) Kanal baru akibat penanaman pohon secara teratur. Penanaman secara teratur telah menyebabkan terbentuknya banyak kanal dan dapat memicu terjadi erosi (Foto T. S. Djohan)

berkurang setelah tebangan industri beroperasi mengindikasikan bahwa banyak gap area bekas tebangan tidak di tanam dengan pohon Rhizophora dan Bruguiera. Pada hal akar pohon Rhizophora adalah habitat nursery untuk larva udang, kepiting, dan ikan yang bernilai ekonomi.

\section{Kondisi Hutan Bekas Base Camp Logger}

Lokasi base camp logger baik di Teluk Air dan Batu Ampar Kecil berupa usikan kecil (small disturbance) dan menciptakan gapkanopi di hutan bakau tersebut. Lokasi kedua bekas base camp tersebut adalah di zona lowe-lower dan berupa dataran lumpur (mud-flat). Luas area pemukiman tesebut sekitar 0,75 ha. Bekas base camp tersebut didominasi oleh pohon $R$. apiculata. Lokasi 
tersebut masih mempunyai pohon tetangga $R$. apiculata. Pohon tersebut merupakan pohon sumber propagul keduabekas base camp tersebut (Gambar 5).

Di hutan bakau Teluk Air bekas base camp didominasi oleh $R$. apiculata dan mempunyai cacah individu 400 pohon per $800 \mathrm{~m}^{2}$ dan densitas relatifnya $100 \%$. Tinggi Rhizophora tersebut $6 \pm 1,4 \mathrm{~m}$ dan diameternya 5,41 $\pm 0,45$ $\mathrm{cm}$. Seperti telah dibicarakan sebelumnya, kolonisasi sapling tersebut tumbuh secara alami. Berdasarkan tinggi dan diameter batangnya, maka dapat dikatakan bahwa umur koloni baru tersebut sekitar 4 tahun (Gambar 3). Artinya rekolonisasi alami pohon bakau di bekas base camp logger tersebut adalah cepat. Jadi dengan kata lain, pemulihan hutan bakau usikan kecil telah menjaga biodiversitas jenis hutan bakau di Batu Ampar.Di lokasi Batu Air juga ditemukan pohon Avicennia alba tingginya juga sekitara 6 meter, dan juga pohon Nypa fruticans. Kedua jenis pohon tersebut ditemukan diluar plot kajian (Gambar 5).

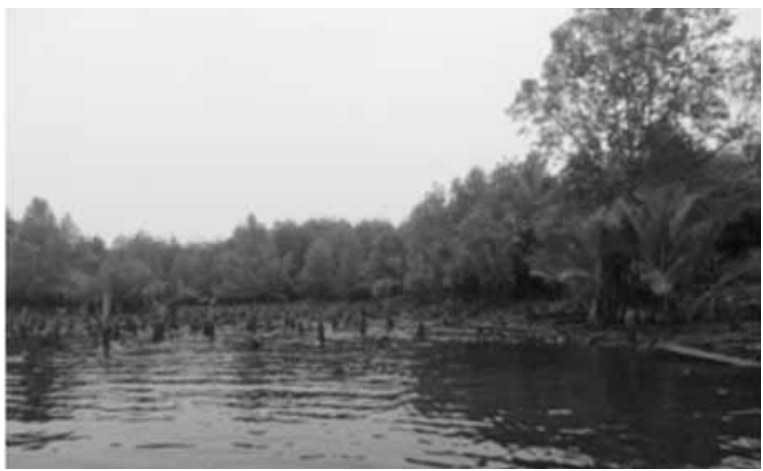

a.

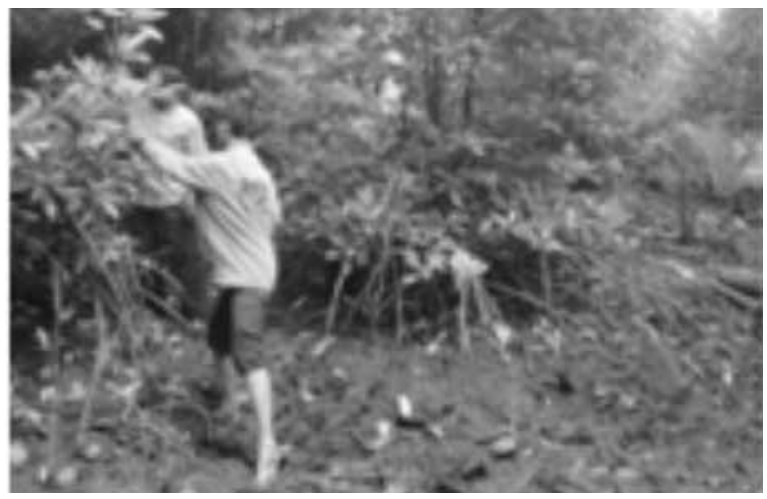

b.

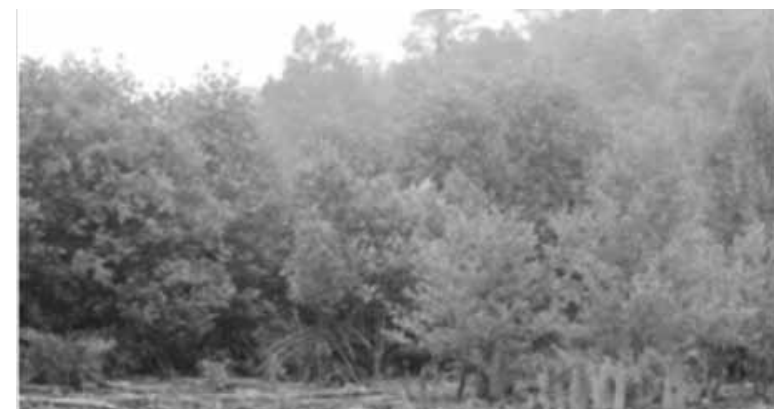

c.

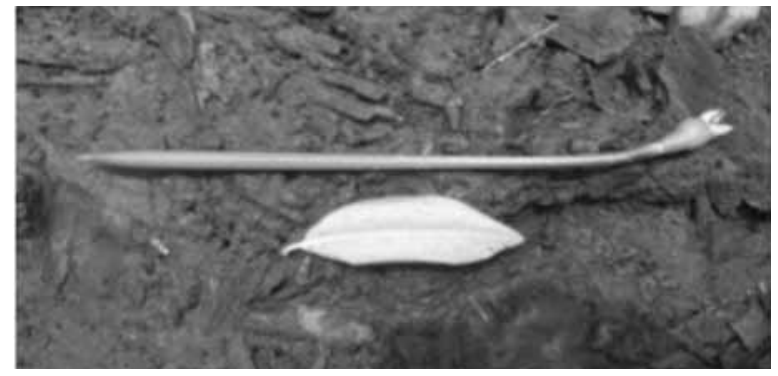

d.

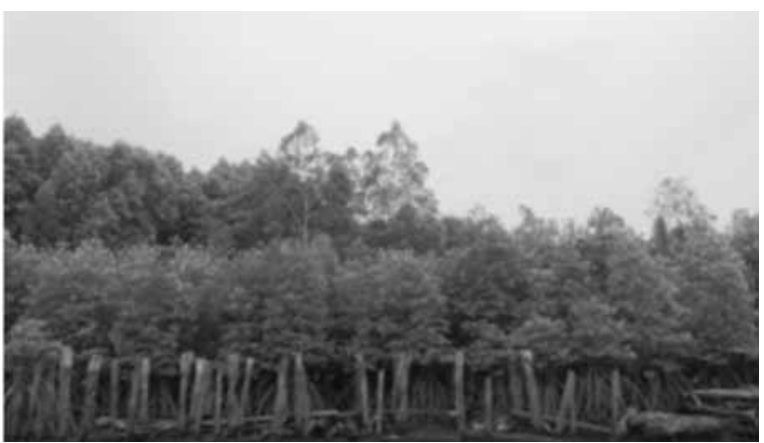

e.

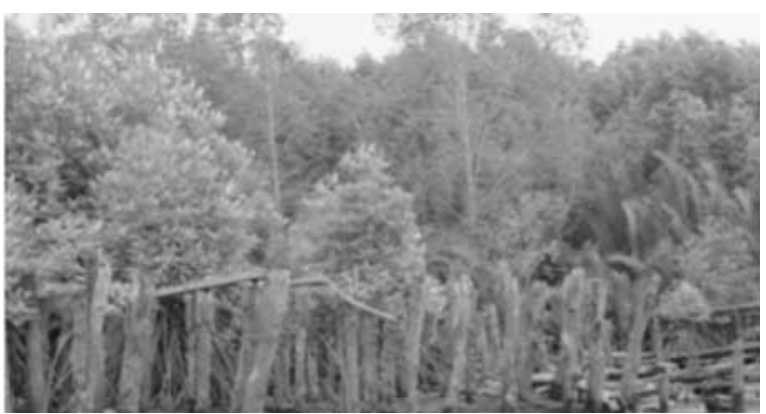

f.

Gambar 5

(a-d) Bekas base camp logger hutan darat dan sisa cagak untuk rumah pemukiman di mud flat Teluk Air. Tumbuhan dominan adalah R. apiculata dan; (c) Avicennia alba dan palem bakau Nypa fruticans.(d) Propagul R. apiculata (buah panjang); (e - f) Bekas base camp tebangan industri, didominsai sapling R. apiculata yang tumbuh alami. Sisa cagak kayu adalah bekas pemukiman logger (Foto T. S. Djohan) 
Keadaan yang sama juga ditemukan di base camp logger tebangan industri di Batu Ampar kecil. Dilokasi bekas base camp tersebut rekolonisasi secara alami dan didominasi oleh sapling pohon $R$. apiculata 1120 batang per $800 \mathrm{~m}^{2}$, tinggi dan diameternya berturutturut $4 \mathrm{~m}$ dan 4,77cm (Gambar 3; Gambar 5). Berdasarkan tinggi dan diameter batangnya, maka dapat dikatakan bahwa koloni $R$. Apiculata tersebut berumur sekitara 3 tahun. Kondisi hutan bakau disekitar bekas base camp tersebut tetap baik, dan didominasi oleh pohon $R$. Apiculata, danini ternyata merupakan sumber propagul untuk sapling pohon penyusun hutan bakau di bekas base camp. Untuk itu dapat dikatakan penebangan hutan bakau oleh dalam skala kecil menciptakan usikan kecil dan tetap menjaga biodiversitas jenis pohon penyusun hutan bakau Batu Ampar.

\section{Pemulihan Hutan Bakau Alami}

Tebangan masyarakat dalam skala kecil ini telah menciptakan gap kanopi dan pemulihan hutannyanya sangat cepat. Hutannya tumbuh secara alami. Gap kanopi hasil tebangan skala kecil di hutan bakau Batu Ampar menyebabkan hutan bakaunya disusun oleh generasi fase gap.Generasi fase gap tersebut tumbuh secara alami dan didominasi oleh jenis $R$. apiculata, $B$. gymnorhiza, dan jugadalam jumlah kecil $X$. granatum. Hadirnya generasi fase gap tersebut mengindikasikan bahwa hutan bakau di Batu Ampar merupakan hutan bakau skunder. Adanya generasi fase gap di hutan bakau tersebut telah menjaga biodiversitas hutan bakau Batu Ampar.Usikan kecil (smalldisturbance) pada tutupan hutan bakau tidak menggangu pertumbuhan hutan kembali. Jadi keanekaragaman jenisnya terjaga. Sebaliknya pertumbuhan hutan tebangan industri di area yang tidak direboisasi, Tanjung 16, hutannya juga tumbuh alami, akan tetapi hutan bakau tersebut didominasi oleh pohon $X$. granatum. Oleh sebab itu, tebangan industri sebagai usikan besar tidak menjaga biodiversitas hutan bakau Batu Ampar dan telah mengancam jasa ekosistem hutanbakau Batu Ampar.

\section{Tipe dan Fungsi Akar Pohon Bakau}

Jenis Rhizophora mempunyai tipe akar yang tumbuh dua arah sebagai akar gantung (stilt root) dan pertumbuhan di dalam jeluk lumpur (prop root). Ketika akar gantung menyentuh tanah, maka akar tersebut akan tumbuh di secara cepatdalam tanah kearah lateral, dan kemudian membentuk satu atau lebih akar baru yang tumbuh tegak kearah udara. Akar tersebut ketika pasang terendam air danmerupakan habitat larva baik udang, kepiting, maupun ikan. Pohon Brugueira gymnorhiza mempunyai tipe akar lutut (knee root). Pertumbuhannya condong dan masuk lagi ke dalam tanah (underground).

Di hutan tebangan industri yang tidak direhabilitasi, seperti telah dibicarakan sebelumnya, hutan bakaunya didominasi 90\% oleh sapling X. granatum. Jadi di hutan bakau Batu Ampar telah terjadi shifted spesies. Tebangan industritelah menciptakan usikan besar, dan di area tebangan tersebut yang dibiarkan tumbuh alami, telah mengubah kekayaan spesies dan hanya didominasi oleh satu jenis pohon bakau. Pohon Xylocarpus akarnya merupakan akar papan. Tipe akar papan bukan tipe untuk habitat perlidungan (nusery ground) larva udang, ikan, dan kepiting yang bernilai ekologi dan ekonomi (Gambar 6).

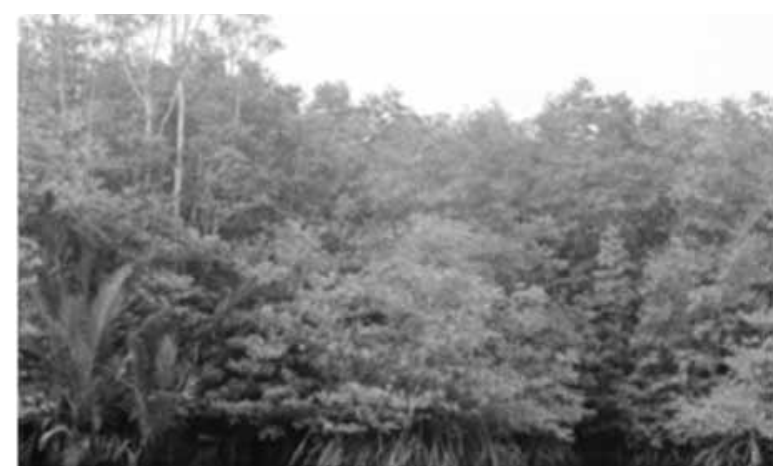

a. 


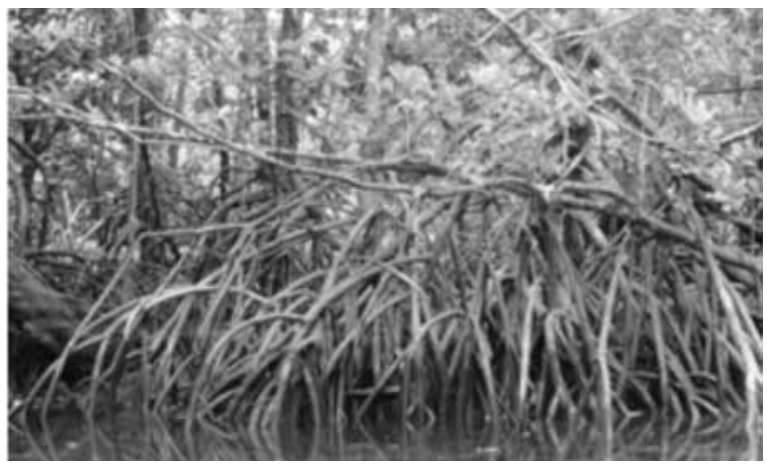

b.

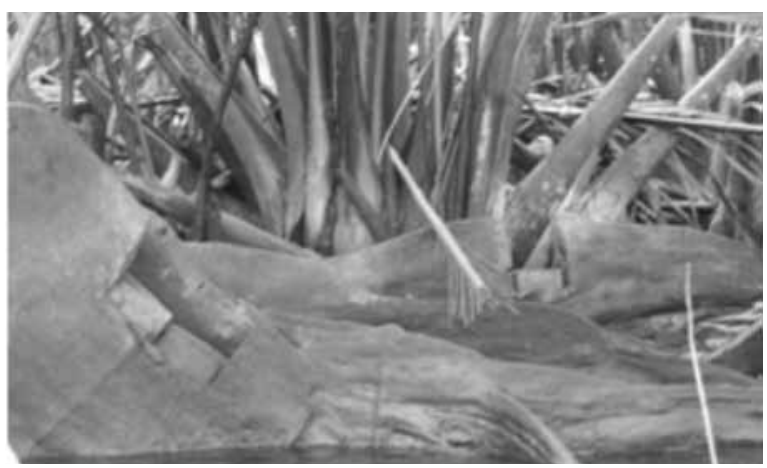

c.

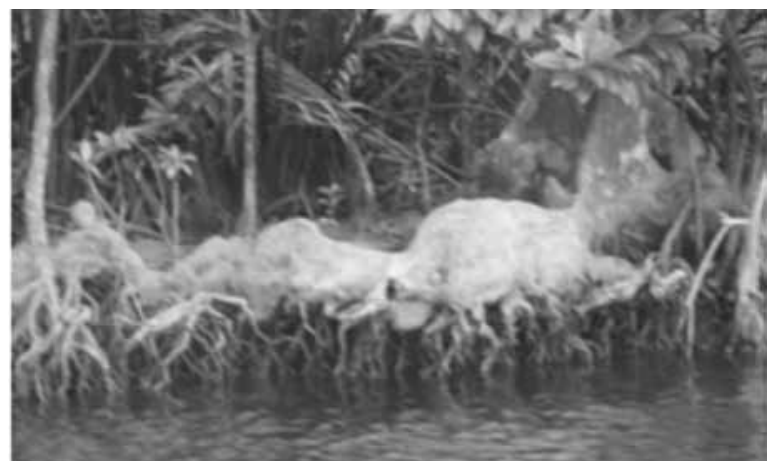

d.

Gambar 6

(a-b)Tipe akar gantung (stilt root) pohon

Rhizophora (buah panjang) dan merupakan habitat larva baik udang, ikan dan kepiting, dan;

(c-d)Tipe akar papan pohon Xylocarpus.Tipe tersebutbukanlah habitat larva udang, ikan dan kepiting bakau.Hutan bakau Batu Ampar, lantai hutannya selalu disapu atau tercuci oleh pasang surut secara periodic (Foto T. S. Djohan)

\section{Kualitas Perairan Kajian dan Keluhan Masyarakat}

Salinitas perairan kajian ketika surut dan menjelang pasang sekitar 6,36-15\% dan $\mathrm{pH}$ 6,36-6,81 (Gambar 7). Kondisi ini merupakan ciri khas perairan hutan bakau. Artinya kualitas perairan hutan bakau Batu Ampar berdasarkan nilai $\mathrm{pH}$ dan salinitas adalah baik.Keluhan masyarakat bahwa setelah tebangan industri pulp beroperasi, penghasilan tangkapan ikan, udang, dan kepiting nelayan berkurang (Laksano dkk., 2014), hal ini dapat dikatakan tidak ada kaitannya dengan kualitas perairan. Akan tetapi, berkurangnya hasil tangkapan nelayan karena habitat nurcery ground untuk larva udang, kepiting dan ikan yang semula disediakan oleh akar pohon Rhizopora telah tidak ada karena telah ditebang habis dalam skala luas.

Seperti telah dibicarakan sebelumnya, lokasi tebangan hutan industri pulp di Tanjung 16 yang tidak direboisasi. Bekas tebangan industri tersebut hutannya tumbuh secara alami,dan struktur hutan bakaunya telah berubah dan dominasi oleh Xylocarpus yang mempunyai akar papan. Akar papan Xylocarpus bukanlah habitat nusery untuk larva udang dan ikan. Jadi berkurangnya penghasilan tangkapan udang, ikan, dan kepiting nelayan ada hubungannya dengan perubahan struktur hutan bakau akibat tebangan industri. Ekosistem hutan bakau Batu Ampar telah kehilangan jasa ekosistemnya sebagai habitat larva udang, ikan, dan kepiting. Tanpa campur tangan manusia untuk rehabilitasi hutan tebangan skala kondisi perairan baik perairan baik, maka dapat dikatakan bahwa ekosistem hutan bakau Batu Ampar dalam keadaan terancam keberlanjutannya.
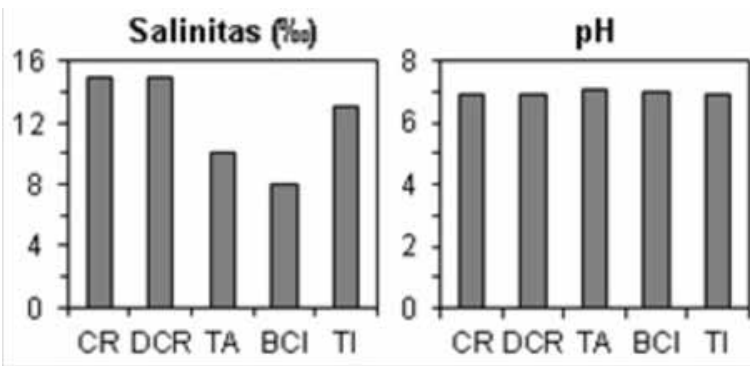

Gambar 7

Kualitas Peraran di Lokasi Kajian meliputi Salinitas dan $\mathrm{pH}$. 


\section{Pengelolaan Hutan Bakau Batu Ampar}

Walaupun tebangan masyarakat dalam skala kecil telah menjaga biodiversitas jenis penyusun hutan bakau Batu Ampar, tetapi bila tebangan skala kecil tersebut dilakukan dalam jumlah yang banyak, maka pemulihan hutannya juga dipertanyakan. Oleh sebab itu, penebangan selektif pohon bakau dalam skala kecil oleh masyarakat juga perlu dikelola. Untuk itu, dalam konsep konservasi, sumber daya ekosistem dalam penggunaannya harus dihemat, digunakan secara bijaksana, dan dilindungi, sehingga jasa ekosistem hutan bakau tersebut berkelanjutan.

Sebaliknya bekas tebangan hutan bakau dalam skala industri yang tidak ditanam kembali atau direboisasi telah merubah struktur hutan bakau. Hutan bakau tebangan industri dalam pertumbuhan hutannya telah kehilangan jasa ekosistemnya sebagai habitat nusery ground untuk larva udang, kepiting, dan ikan yang bernilai ekonomi. Akibatnya hasil tangkapan nelayan berkurang, dan sumber mata pencahariannya terganggu. Area hutan bakau tebangan industri tersebut harus segera ditanam dengan Rhizophora apiculata dan Bruguiera gymnorhiza. Penanamannya tidak boleh teratur karena menciptakan banyak kanal arus dan memicu erosi. Jadi penanaman propagul atau seedling pohon bakau tersebut dilakukan secara tidak teratur seperti tumbuhnya dialam.

\section{SIMPULAN}

Berdasarkan kajian lapangan, maka dapat disimpulkan bahwa tebangan hutan bakau skala industri menciptakan usikan atau gangguan skala besar dan telah mengancam ekosistem hutan bakau Batu Ampar. Pemulihan alami hutan di bekas tebangan industri telah merubah struktur penyusun hutan bakau karena jenis dominan adalah $X$. granatum. Penebangan hutan bakau dalam skala besar telah menyebabkan terjadinya shifted jenis pohon bakau dari $R$. apiculata menjadi $X$. Garanatum. Akar pohonnya bukanlah habitat nurcery untuk baik larva udang, kepiting, maupun ikan. Perubahan ini telah menyebabkan hutan bakau Batu
Ampar telah kehilangan salah satu jasa ekosistemnya, yaitu sebagai habitat nusery ground baik larva udang, ikan, dan kepiting. Penebangan industri telah mengancam jasa ekologi hutan bakau sebagai habitat nusery ground dan juga ekonomi nelayan Batu Ampar. Sebaliknya tebangan hutan bakau oleh masyarakat dalam skala kecil, 0,25 ha adalah tidak merubah komunitas jenis penyusun hutan bakau. Hutan bakaunya disusun oleh generasi fase gap yang didominasi oleh pohon bakau $R$. apiculata dan B. gymnorhiza. Penebangan pohon bakau masyarakat dalam skala kecil tersebut telah menjaga biodiversitas jenis penyusun hutan bakau Batu Ampar.

\section{UCAPAN TERIMAKASIH}

Kajian ini didanai oleh The Asia Foundation melalui Pusat Studi Asia Pasifik Universitas Gadjah Mada dan Perkumpulan PENA, didukung oleh KONPHALINDO, USAID, dan Epistema Institut. Terimaksih disampaikan kepada: Pak Budi dari Batu Ampar, Pak Rinto dan dan ibu C. Pancer P. dari Perkumpulan PENA, Pak R. Gustave dari KONPHALINDO atas bantuannya di lapangan.

\section{DAFTAR PUSTAKA}

Amir, A. A. 2012. Canopy gaps and the natural regeneration of Matang mangroves. Forest Ecology and Management269: 60-67.

Barbour, M.G., J.H. Burk, and W.D. Petts. 1987. Terrestrial plant ecology, $2^{\text {nd }}$ edit. The Benyamin/cumming Publ. Co. Inc. California.

Djohan, T. S., K. Suhesthiningsih, dan A. A.Akbar. 2014. Kemelimpahan vegetasi penyusun hutan bakau di habitat tebangan Segara Anakan, Cilacap. Laporan Penelitian Hibah Dosen Pasca UGM.

Djohan, T. S. 2007. Mangrove succession in Segara Anakan, Cilacap. Berkala Ilmiah Biologi 6 (1): 53-62. 
Laksono, P. M., T. S. Djohan, Sumijati, A. S., Suhardi, Irham, A. Supryono, H. G. Z. Mulki, E. Anantasari, Chatarina, P. I., P. Kusuma, J. A. Sonjaya, A. Rianty, R. Gustave, Rinto, dan A. N. Utama. 2014. Hutan Bakau Batu Ampar: Keniscayaan Pengelolaan Kolaboratif. Policy Brief Pusat Studi Asia Pasifik UGM 1:1-4.

Mitsch, W. J., and J. G. Gosselink. 2000. Wetlands. $3^{\text {th }}$ edit. John Wiley \& Son, Inc. New York.

Odum, E. P.1971. Fundamentals of Ecology. $3^{\text {th }}$ edit. W. B. Sounder Co. Philadelphia.

Rejmanek, M. 1984. Pertubation-dependent coexistence and species diversity in ecosystem.In Stochastic phenomena and chaotic behavior in complex systems. ed. P. Schuster. pp. 220-230. New York. Springger-Verlag.

Ronnback, P. 1999. The ecological basis for economic value of seafood production supported by mangrove ecosystems.Ecological Economic 29: 235-252.

and J. H. Primavera (2000). Illuminating the need for ecological knowledge in economic valuation of mangrove under different management regimes - A critic. Ecological Economic 35 ( 2): 135-141.

Soerjowinoto, M.1982. The Cilacap mangrove ecosystem. Proceeding of workshop on coastal resources management in the Cilacap region. The Indonesian Institute of Sciences and the United Nations University. Jakarta: 57-65.

Vogt, J. C. Piou, and U. Berger. 2014. Comparing the influence of largeand small-scale disturbances on forest heterogeneity: A simulation study for mangrove. Ecological complexity 20: 107-115. 